\title{
Environmental indicators of ecological integrity and their development for running waters in northern Portugal
}

\author{
S. V. Oliveira \& R. M. V. Cortes
}

CEGE - Study center in management of ecosystems, Forest Department, University of Trás-os-Montes e Alto Douro, Apart. 1013, 5001-911 Vila Real, Portugal. E-mail: simonev@utad.pt; Tel: 351 259350862; Fax: 351 259350480. E-mail: rcortes@utad.pt; Tel: 351 2593500863; Fax: 351259350480.

\begin{abstract}
The recognition of deleterious effects of the destruction and loss of habitats (e.g. regularization of rivers, dredging, water diversion), chemical pollution, eutrophication, and climatic alterations on the aquatic organisms, as a result of human activities, combined with an urgent need of a more environmentally sensitive and ecologically sustainable management of Portuguese river systems, made us seek methods that assess the ecological condition of these systems. This article tries to make a revision of the concept of ecological integrity and the methods commonly used to assess it. Different approaches to establish the reference condition for bio-assessment are also indicated. Finally it shows the new methodologies that have been developed in Portugal for assessing the ecological condition of streams and new directions in the evaluation processes based on a better understanding of the entire aquatic ecosystem are also pointed out. An enormous challenge consists in the integration of various measurements of riverine attributes founded on key ecological processes, and in the development of more dynamic approaches that might together establish river condition and their dependence along multiple temporal and spatial scales.
\end{abstract}

Key words: Ecological integrity, basins, biomonitoring, reference sites, multivariate analysis, multimetric techniques, stochastic-dynamic models.

\section{RESUMEN}

El reconocimiento de los efectos deletéreos de la destrucción y pérdida de hábitat (por ejemplo la regularización de ríos, el dragado o la extracción de agua), la polución química, eutrofización y alteraciones climáticas en los organismos acuáticos, como resultado de las actividades humanas, combinados con una necesidad urgente de una gestión ambientalmente más sensible y ecológicamente sustentable de los sistemas lóticos portugueses, nos incito a buscar métodos que evalúen la condición ecológica de estos sistemas.

Este artículo intenta hacer una revisión del concepto de integridad ecológica y los métodos usados para evaluarlo. También son abordadas maneras diferentes de establecer la condición de referencia para la evaluación biológica. Finalmente muestra las nuevas metodologías que se han desarrollado en Portugal para evaluar la condición ecológica de los ríos y también son indicadas las nuevas direcciones en los procesos de evaluación basados en un mejor entendimiento de todo el ecosistema acuático. Un desafio enorme consiste en la integración de varias dimensiones de atributos fluviales fundamentada en los procesos ecológicos importantes y en el desarrollo de métodos más dinámicos que juntos podrán establecer la condición de los ríos y su dependencia a lo largo de múltiplas escalas temporales y espaciales.

Palabras clave: Integridad ecológica, cuencas, biomonitorización, localidades de referencia, análisis multivariado, técnicas multimétricas, modelos estocástico-dinámicos.

\section{ECOLOGICAL INTEGRITY}

The term "ecological integrity", which AngloSaxon authors also define as "river health" or "ecological condition", is frequently used in monitoring studies of water resources as a measure of the global condition of aquatic ecosystems.
Although the first attempts to define the "health" of aquatic ecosystems have not reached consensus, Karr (1992) uses these three expressions interchangeably given the similitude of the components. Nevertheless, Suter (1993) insists that "health" is an inappropriate metaphor in an ecological context since it is a property only observable 
in organisms. Campbell (2000) agrees with Suter that the use of these concepts is useless, and that operational definitions of these terms are necessary (ecological integrity and ecosystem health). Consequently, Campbell concludes that ecological integrity is an ecosystem property that reaches the highest level when its structure is complete and when all processes inside it work perfectly.

Schofield \& Davies (1996), following Karr \& Dudley (1981) and Angermeier \& Karr (1994), defined ecological integrity as the ability of aquatic ecosystems to support and maintain key ecological processes and an adaptive community of organisms having a species composition, diversity, and functional organization comparable to that of natural habitats of the same region. Edwards \& Ryder (1990) recently used the expression "harmonic community" in a similar context to describe the goal of restoration of the ecological integrity of North American lakes. According to Rapport et al. (1998), the health of an ecosystem has been defined not only in terms of system organization, vigor, and resilience, but also by the absence of environmental stress. Karr et al. (1986) points out that healthy ecological systems have a high capacity to resist the disturbances imposed by natural environmental phenomenon's and many alterations induced by society, therefore they require a low external intervention. However, nowadays, it is almost impossible to find an area completely unaltered (pristine) by human activities, the term "minimally" disturbed becoming more appropriate to describe the expected conditions in sites that exhibit high biological integrity. EPA (1998) agrees with this concept of integrity, considering that it represents a system that is balanced, adaptable and that reflects the natural evolutionary processes.

In addition to the definitions introduced above, many others could be mentioned without, however, objectively add much more to what it has been already referred to. It means that, in spite of the vast group of definitions and designations used for the term ecological integrity (considered synonyms of river health or ecological condition), it will be convenient that all these concepts converge into an unique one, that can be translated as being the natural state of the ecosystems

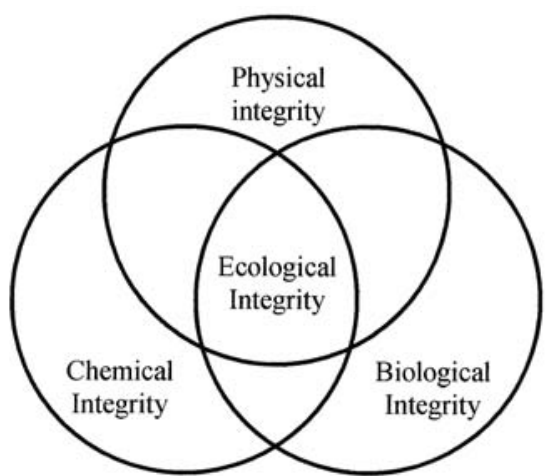

Figure 1. Ecological integrity and its three elements: physical, chemical and biological integrity (from Barbour et al., 2000). Integridad ecológica y sus tres elementos: integridad física, química y biológica (de Barbour et al., 2000).

where the changes that can arise are due to the evolutionary dynamics without human influence.

The designation of integrity appeared for the first time associated with the aquatic ecosystems in the United States of America, in "U.S. 1972 Water Pollution Control Act Amendments" now called the "Clean Water Act". Through this act, the importance of this concept was recognized as being fundamental for the whole hydrobiological systems and, as a consequence, they were imposed as objectives for the restoration and maintenance of the physical, chemical, and biological integrity of the USA's waters (Fig.1).

The Water Framework Directive (WFD), Directive 2000/60/CE of 23 October 2000, constitutes an innovating framework for community action in the field of water policy, since it asserts that the definition of water quality depends on its "ecological status", independently of the actual or potential uses of those waters. The ecological status results from the assessment of surface water bodies, and it is defined by the global expression of the structure and functioning of biological communities, taking into account physiographic, geographical, and climatic factors as well as the physical and chemical descriptors, including the ones that are the result of human activities. This type of approach to the ecological integrity must consider the concept presented by Yoder (1995), which shows that the overlapping influence of the three key components (physical, chemical and biological integrity) is unequal and dynamic (Fig. 2). 


\section{Assessment of the ecological integrity}

Traditionally, stream quality evaluation has been based almost exclusively on the measurement of physical and chemical characteristics and it has been disdainful to biological ones. However, the confirmation that the commonly used techniques do not cover the whole interval of biogeochemical factors, and the recognition of the existence of interactions between anthropogenic pressures and its cumulative impacts, is emphasized by the need to search for new and more appropriate means of an ecological condition assessment of water resources for an embraced management of the watersheds.

The recent world trend is the introduction of the biological assessment in the monitoring and evaluation of aquatic resources due to the increasing recognition of its importance in providing a measure of the global integrity, since the aquatic organisms embrace and reflect the cumulative effects of the environmental disturbance and stream pollution (De Pauw \& Vanhoren, 1983; Karr, 1991; Yoder \& Rakin, 1998; Karr \& Chu, 2000) (Fig. 3). Biological indicators can, for that reason, reflect disturbances that would not be detected in another way or that would be otherwise underestimated (e.g. habitat degradation, highly variable pollution levels due to point and non-point pollution).

Due to their capacity to assess aquatic ecosystems integrity, biological evaluations can

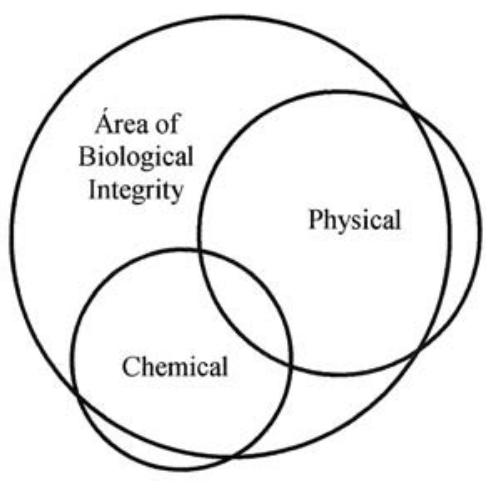

Figure 2. Dynamic model of biological integrity. Pattern established after Yoder (1995) (from Barbour et al., 2000). Modelo dinámico de integridad biológica, patrón establecido siguiendo a Yoder (1995) (de Barbour et al., 2000). complement the chemical and toxicological methods that are necessary for risk prediction (particularly for human health and wild life assessment). They can also be used to diagnose and monitor problems when they are detected (OEPA, 1990; Hyland et al., 1998). In agreement with Karr (1999), from the whole sets of data that describe the condition of rivers and their adjacent landscapes and from the diagnosis of the causes of degradation, we can develop restoration plans to calculate the ecological risks associated with land use plans in a basin, or to find alternative options to minimize the verified deterioration.

Biological monitoring programs have been developed with different purposes, such as: (a) general ecological status surveillance of aquatic ecosystems; (b) setting up protection and restoration goals; (c) diagnosis of specific environmental problems; (d) evaluation of impacts (before and after a pollutant source or upstream and downstream of a disturbance focus); (e) assessment of the agreement between applied management procedures with the ecological goals or quality standards; (f) long term trends detection as a result of different impacts, and (g) effective analysis of rehabilitation measures.

The biological composition of rivers is strongly influenced by the physical habitat, since it provides the support of ecological organization and lotic ecosystems dynamics (Minshall, 1988; Poff \& Ward, 1989; Townsend \& Hildrew, 1994; Maddock, 1999). Therefore many assessing programs have been incorporated in habitat evaluations (e.g. Plafkin et al., 1989; Wright, 1995; NRA, 1996).

Given the importance of the evaluation of the different ecosystem components following an ecological condition assessment approach, we have been developing in Portugal methods that comprise, in some way, the several components of the fluvial ecosystem (physical, chemical and biological). The goal is consequently to obtain the mentioned integrated comprehension of the lotic ecosystems, and at the same time to assess the interactions among the fluvial channel, riparian corridor and drainage basin, as well as their temporal dynamics. 

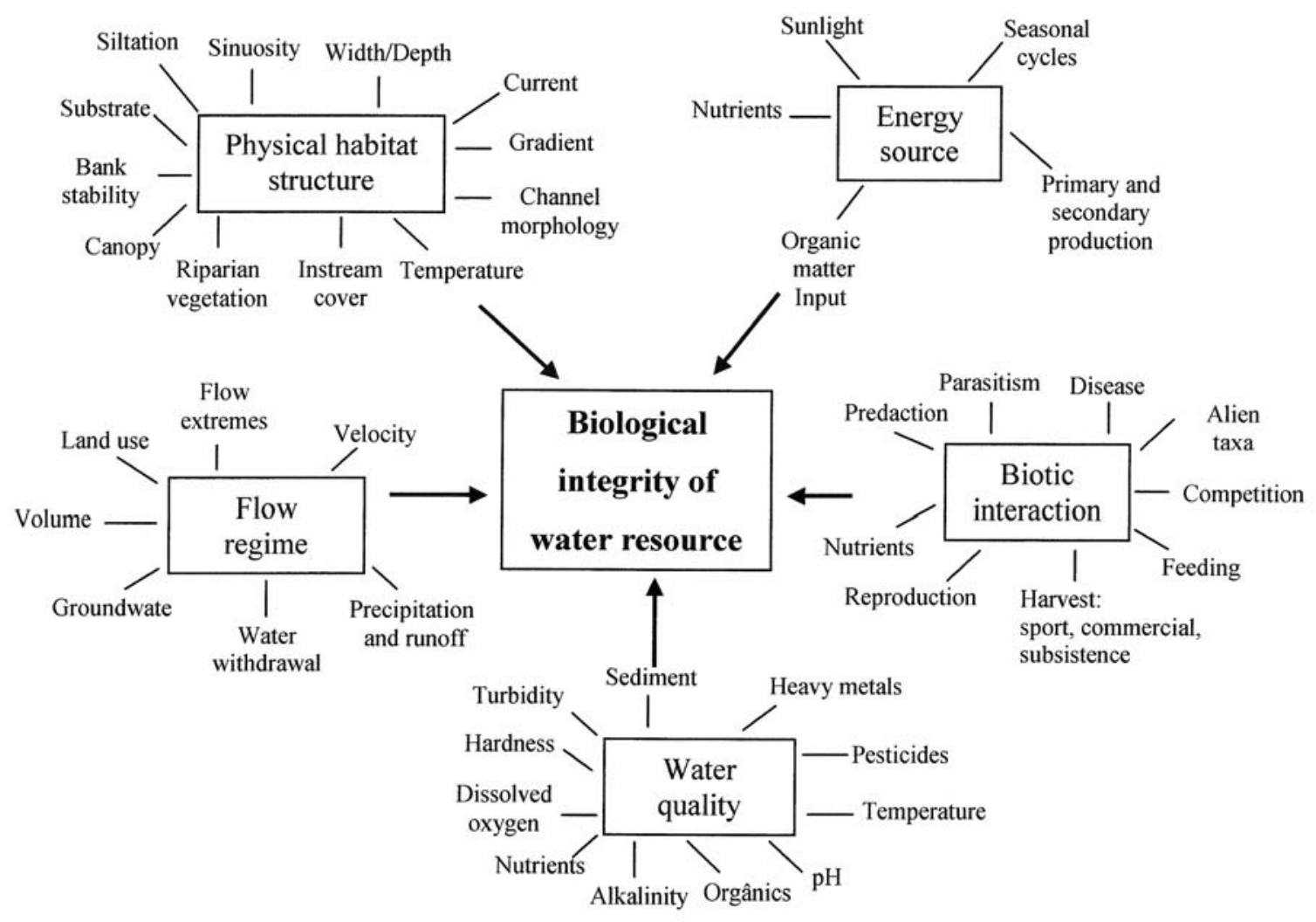

Disease

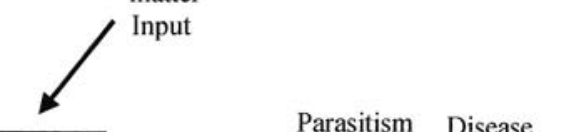

Nonpoint sources

Point sources

Figure 3. Schematic representation of the five principal factors that influence the aquatic resources' integrity and that are usually altered by human activities (adapted from Karr and $\mathrm{Chu}, 2000$ ). Representación esquemática de los cinco factores principales que influyen en la integridad de los recursos acuáticos y que normalmente se alteran por las actividades humanas (adaptado de Karr y Chu, 2000).

\section{Ecological integrity evaluation methods}

Nowadays, a great number of methods, which range from relatively simple algorithms or biotic indices, to combinations of multiple community descriptors (multimetric approach) and complex algorithms (multivariate methods), are available to assess the ecological condition of running waters. These last two broad systems, developed independently in the United States and in Europe, emerged in the last 25 years and today are widely used in biological monitoring. The underlying principle of these two techniques is that the organisms are the final integrators of all human actions.

The first model, the multimetric indices (like the Index of Biotic Integrity - IBI; Karr, 1981), was developed in order to measure the biotic integrity based on fish communities. The concept was adopted quickly and similar indices, based on modifications to the original IBI concept, have been developed. These indices have been applied in various animal communities (e.g. macroinvertebrates, fishes, riparian birds and amphibians), vegetable communities (e.g. phytoplankton, periphyton, macrophytes, riparian vegetation), in floodplains, rivers and estuary zones, and they have also been adapted to terrestrial ecosystems (Bradford et al., 1998; Karr \& Chu, 1999).

According to Klemm et al. (2003), the logical reason that supports all these techniques, independently of the biotic community used, is that the set of representative community structure metrics or attributes (species richness, relative 
abundance, dominance, composition and ecosystem functioning) must offer robust and sensitive tools to measure the anthropogenic disturbance factors in those communities. Effective multimetric indices imply explicit rules such as: a) an appropriate classification system; b) a metric selection that supplies safe signs of river condition; c) systematic sampling protocols that standardize the field procedures; d) statistical techniques that can extract important biological patterns (Karr, 1999). Barbour et al. (1996) claims that the multimetric model, since it involves several aspects of the community structure and function, can still be considered as a powerful tool to assess non-point pollution effects in aquatic organisms. According to Karr \& Chu (2000) the biological monitoring carried out through the multimetric methods, such as the index of biotic integrity, supplies one of the most robust tools available to diagnose, minimize and prevent the degradation of aquatic systems.

Rapid Bio-assessment Protocols (RBPs) based on multimetric approaches, developed in the USA in the mid-1980s by Plafkin et al. (1989), are also much used nowadays in this country and elsewhere. These protocols advocate an integrated assessment of aquatic resources, comparing biological communities (fish, invertebrates, and periphyton), habitats (e.g. physical structure, flow regime), and water quality with empirically defined reference conditions (Barbour et al. 1999).

The second system relies on multivariate statistical methods to discern patterns in community composition. Some examples include RIVPACS (River Invertebrate Prediction And Classification System - Wright, 1995), developed and applied in the United Kingdom, and its derivatives such as AusRivAS, (Parsons \& Norris, 1996) adapted for Australia. RIVPACS is a predictive model that compares the "observed" macroinvertebrate fauna composition at a given site with the "expected" fauna (which represents the reference condition) for the same site in the absence of environmental stress. The expected fauna is predicted from a small suite of environmental variables of the site (geographic variables, geology and habitat descriptors), which are considered as relatively stable through time and "minimally" impaired. With

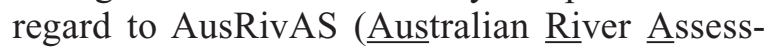

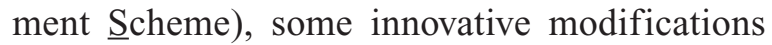
concerning the sampling strategy, geographical covering, taxa selected, model building, software, support information and outputs were introduced to the original model RIVPACS (Davies, 2000). Thus, as examples, we can say that, unlike RIVPACS, different models were developed for distinct geographical areas; the habitats were sampled separately allowing both single and multiple habitat assessments and only the selection of those taxa having $\geqslant 50 \%$ probability of occurrence. Some of these differences took advantage of the progresses in computational techniques and statistics, while another necessarily appeared due to the singular environment of Australia (Simpson \& Norris, 2000). Actually, AusRivAS can be accessed and run via the Internet by authorized users.

Another multivariate procedure is the predictive model BEAST (BEnthic Assessment of SedimenT - (Reynoldson et al., 1995)), developed initially for the Laurentian Great Lakes and, in a second phase, for the basin of one of the largest Canadian rivers (Fraser River). It comprises a set of reference sites that characterize the pristine biological condition (macroinvertebrate communities) of a region and test sites, which are then compared to the appropriate subset of reference sites Rosenberg et al. (2000). For the Great Lakes, the reference sites were chosen using ecodistricts to stratify sample sites located in shallow, non-impacted or clean areas near the shore, with fine-grained sediments and. For the river Fraser, ecoregions and stream orders were used within ecoregions. In the final stage (test site assessment), the BEAST technique uses a probability model based on taxa ordination space and the "best fit" of the test site(s) to the probability ellipses constructed around the reference site classes (Reynoldson et al., 1995). Because this model does not consider the probability of a test site to be incorrectly placed in another reference group, Reynoldson et al. (1997) recommends the use of the three models previously described (RIVPACS, AusRivAS and BEAST) since they are complementary. 
Although both approaches (multivariate and multimetric) are largely used, they have not been applied without criticism. For instance, Suter (1993) explains that indices such as IBI "are justified in a base of field works and not in any theory of ecosystem health or any social or ecological index value or of its components". Furthermore, Suter outlined that these indices can present a series of potential faults such as ambiguity, arbitrary combining functions, arbitrary variances, nonsensical results, and unreal or improper analogy to other indices. Also Reynoldson et al. (1997) points out that multimetric methods, despite that they can be attractive because they provide a global indication of ecological status at a site, incorporate metrics that are frequently redundant, while not all the obtained information is used. In opposition to this idea, Karr \& Chu (1999) stress that, notwithstanding that the metrics are not independent, because they are calculated from the same group of organisms, it does not mean that they are necessarily biologically redundant, even if metrics are statistically correlated. Moreover, there is less uncertainty when more than one metric (multiple measures) point simultaneously to a degradation symptom (Smith, 1994; Karr \& Chu 1999).

With regard to multivariate methods, Fore \& Karr (1996) claim that these are more appropriate for exploratory analyses when the investigator has a limited knowledge of an ecological system and wants to create hypotheses that can be tested. These authors also argue that a method that incorporates ecological information, like, for instance, a good multimetric index, is more appropriate for biomonitoring than mere statistical algorithms.

Karr \& Chu (1999) emphasize that multivariate analyses were developed for finding patterns and not for assessing impacts, and that wrong interpretations of results are more common by using these techniques than through the multimetric approaches. De Pauw (2000) says, in relation to RIVPACS, that although it is one of the best available methods for assessing the biological quality of rivers, it becomes inadequate when the method does not consider the dynamism of biotic communities (i.e. the envi- ronmental variables selected are resilient to change - Johnson, 2000).

Norris \& Thoms (1999), outline that the mentioned techniques, if based in indices, allow for rapid biological assessments (e.g. IBI, RIVPACS, AusRivAS), offering reductions in costs compared to traditional methods. They still supply a clear form to present and summarize the results of site surveys, which are expressed into a score that can be understood by non-specialists. Regarding the mentioned advantages, the use of these methods allows for monitoring to acquire, more and more, an extensive character in a regional plan instead of intensive biological assessments at the local scale. However according to Jackson et al. (2000), when the selection of an indicator and its implementation in a monitoring program depends significantly on the chosen model, the best strategy is to make use of several models and to give priority to those indicators that emerge repeatedly during that exercise. Fairweather (1999) points out that the next stage should be the development of indicators with a dynamic perspective, based on more direct measures of ecological processes. De Pauw (2000) reinforces the idea by adding that to develop a predictive dynamic system information of temporal variability should be collected and introduced in an intelligent system as decision trees, based on the use of neural networks or other artificial intelligence (AI) techniques. Despite the criticisms, and in agreement with Johnson (2000), that coordinated the compilation of the discussions during an international meeting, we believe that the combination of multivariate and multimetric methods may synergistically improve the value of these two approaches in biomonitoring. They should be looked on as complementary instead of competing approaches.

\section{DEFINITION AND SELECTION OF REFERENCE SITES}

The pressure of increasing human population accompanied by intensified agriculture and the urban and industrial development has led to the 
extensive degradation of water quality and habitat leaving very few river segments unaffected by human activities. The recognition, inside the European Union (EU), of the limited number of high quality sites has led to a larger interest in its identification, assessment, protection, preservation, and, ultimately, restoration (REFCOND guidance, 2003). The conservation of these reaches is important because they represent a historical value of ecological conditions closer to the natural ones. Reference conditions (RC) may range from "pristine" to "best available" ones, and are usually based on the status of the communities in reference sites, which are relatively unaltered and homogeneous with regard to the morphological, hydrological, physico-chemical, and biological conditions. These conditions can be defined by only one biological element, just as the invertebrate fauna, or for the combination of several taxonomic groups (e.g. fish, macrophytes) or functional attributes (e.g. growth rates, functional groups). In deeply modified rivers, to resort to the best available sites seems to be one of the solutions for assessing the maximum ecological potential. Therefore, the establishment of reference conditions serves as control for the monitoring/conservation programs that intend to assess the ecological status of rivers and the degree of deviation to relatively natural conditions in similar environments.

Although a lot of definitions exist for the reference condition, we are in agreement with Johnson (2001), in that the multiplicity of results, nearly always ends in misinterpretations and disagreements. Johnson also stresses that much of the ambiguity involving the definition and use of reference conditions is due, in great part, to the way we perceive our surroundings and the study's objectives.

Biotic communities comparisons among relatively undisturbed reference reaches and disturbed sites have become the recommended method of water quality monitoring (Wright et al., 1994; OEPA, 1987, 1989; Plafkin et al., 1989; Karr, 1991; Rosenberg \& Resh, 1993; Davis \& Simon, 1995; Barbour et al., 1996, 1999). They also serve to establish restoration goals and for monitoring progress in achieving those goals (Hughes et al., 1986; Hughes, 1995). Due to recognized importance of this concept, the document "REFCOND guidance (2003)", produced by the European Commission for the implementation of WFD for its member states, proposes definitions, methods, principles, and criteria that can be used in the establishment of reference conditions and classes of ecological quality for lakes and water courses. This document states that each type of surface water body sites with high ecological status should be identified namely by the hydromorphological, physico-chemical, and biological conditions that characterize such reference sites.

\section{Methodologies for the establishment of reference conditions}

According to Norris \& Thoms (1999), a previous classification of river types is essential for the establishment of the reference sites in order to reduce biological variability within different water bodies. Classification schemes of rivers include those based exclusively on geo-morphological features of the drainage basins (Rosgen 1994, 1996), in ecoregions (areas with the same climate, physiography, geology, soils and native vegetation - e.g. Hughes \& Larsen, 1987; Plafkin et al., 1989, Omernik, 1987, 1995), and those that use multivariate analyses (or predictive models) of biological attributes (Wright et al., 1984; Parsons \& Norris, 1996). In relation to these last methods, it has been pointed out that they are more appropriate in the basins' medium and superior segments, once in lowland areas the systems are more intensely transformed (e.g. Petts, 1989; Thoms et al., 1999; Norris \& Thoms, 1999).

Methods for the recognition of reference sites, or minimally disturbed ones, have been proposed by several authors. Thus, the reference biological conditions for each type can be defined from existing reference sites, or from historical, paleo-ecological and experimental data, which can be obtained in the laboratory, or through modeling, extrapolation and based in expert judgment. A brief description of the methods above mentioned, based essentially on the articles of Johnson (2001) and Economou et al. (2002) is presented below. 
a) Expert judgment and/or historical data

The success of the use of these two methodologies in the monitoring and environmental assessment is limited. While the evaluation of the reference condition for experts has the potential of combining a broad range of important information (historical data and/or actualized opinions and concepts), this approach can introduce subjectivity and an incapacity to reach quantitative and standardized procedures. Nevertheless, even if other methods have been used to define the reference condition, an expert opinion is always necessary, at least, in data quality evaluation when monitoring objectives and methods have changed along the time.

Historical data provides not only the knowledge of past conditions, but it becomes essential to estimate the current ecological potential. For the reconstruction of past periods various sources of data can be used such as: old maps, photos, scientific records, oral histories, etc. These methods are particularly important in degraded systems. Despite the fact of being less subjective than those based on expert opinion, they have the disadvantage of not allow knowing with accuracy the past environmental conditions. In fact, reference conditions do not stay static in time; therefore alterations of the ecosystem components should be examined within the current climate period. One of the largest disadvantages ascribed to the use of these two methods is not including the dynamic and inherent variability often associated with natural ecosystems.

\section{b) Extensive surveys (spatial distribution)}

Data from the reference sites can be grouped $a$ priori or a posteriori into homogeneous strata, representative of the area and water bodies in analysis, and used to estimate the natural amplitudes of biological variability and establishing reference condition. The common practice is to define sites a priori rule-based and/or quantitative exclusion criteria concerning specific types of impacts (e.g. absence of canalization or dredging, lack of dams and water extraction, lack of point pollution sources, unaffected land-use patterns, absence of exotic species, etc.). Sites that do not satisfy the pre-defined criteria are then excluded. This methodology, also designated as a priori, nowadays is applied in most of the USA (multimetric approaches) and uses independent geophysical and chemical data to group pristine or "minimally" disturbed sites. However, if the selection is made a posteriori (the exclusion is decided after monitoring), it is important not to exclude sites with low natural variability and caution should be taken not to introduce circularity by using variables that will be used subsequently in the classification of the ecological status. Analysts who use multivariate approaches (e.g. RIVPACS, AusRivAS and BEAST models) tend to use the $a$ posteriori classification of sites. This approach, in contrast with the a priori method, uses the species composition in reference sites, based on clustering methods, to define the reference condition (Wright et al., 2000). The ecological status of a river is later estimated by comparing metric values of a population of test sites with metric values of the reference population, for the same river type in the same geographical area. According to Barbour et al. (1999) there is no reason a priori classification could not be used with multivariate assessments, and vice-versa.

As advantages of this kind of procedures Economou et al. (2002) highlights the fact that reference conditions could be measured directly in the field and could accommodate the natural variability. They also refer to disadvantages, essentially due to the high sampling cost, especially when we intend to take variability into account by increasing the number of surveyed reference sites. According to the same authors, both a priori and a posteriori delineation processes are of extreme importance in the establishment of methodologies and criteria for reference site selection.

An intermediate between these two approaches was used for reference site selection in the study developed by Oliveira \& Cortes (2006a), with the aim of take into account the advantages of both methods, and to show that their relation depends on the information available for the studied region.

\section{c) Paleo-reconstruction and/or modeling}

These type of techniques are particularly important when the ecosystems are heavily disturbed, 
Table 1. Strengths and weaknesses of methods normally used to establish the reference condition (from Johnson, 2001). Ventajas y desventajas de los métodos normalmente usados para establecer la condición de referencia (de Johnson, 2001).

\begin{tabular}{|c|c|c|}
\hline Approach & Strengths & Weaknesses \\
\hline Expert opinion or best judgement & $\begin{array}{l}\text { May incorporate both historical data/ } \\
\text { opinion and present-day concepts }\end{array}$ & Bias may be present \\
\hline Historical data & Often inexpensive to obtain & $\begin{array}{l}\text { Variable data, few metrics and data } \\
\text { quality may be poor or unknown, } \\
\text { static measure }\end{array}$ \\
\hline Paleoreconstruction & $\begin{array}{l}\text { Incorporate both physico-chemical } \\
\text { and biological data }\end{array}$ & $\begin{array}{l}\text { Basically limited to lentic systems, } \\
\text { high initial costs }\end{array}$ \\
\hline Direct & Site-specific & Not many metrics \\
\hline Indirect & $\begin{array}{l}\text { Calibration models currently available } \\
\text { for modelling a number of stressor } \\
\text { variables; } \mathrm{pH} \text {, Total phosphorous, } \\
\text { temperature } \\
\text { reconstruction }\end{array}$ & \\
\hline Modelling & Site-specific & $\begin{array}{l}\text { Requires data, calibration and } \\
\text { validation }\end{array}$ \\
\hline Survey & Region-specific & Expensive to initiate \\
\hline
\end{tabular}

not being possible to find reference sites (minimally impaired), and/or when the available information is very scarce also for artificial water bodies like reservoirs or canalized rivers. Paleo-reconstruction seeks to obtain records of the geo-morphological, physico-chemical or biological modifications that happened throughout time in a water body. This procedure is applied essentially to lakes and only very rarely to rivers. Also in this case the past reference conditions cannot be representative of the current conditions, the opinion of experts being important to integrate all the information along relatively vast temporal periods.

The expected reference conditions to a given site can also be predicted by modeling. The two more used methods are: i) extrapolation of a cause-effect relationship (stress-response). It allows to predict, for the same area, the expected value of a metric in the absence of human disturbance; ii) estimation of the pristine condition outside the area to which the reference condition was established. This approach establishes relationships (e.g. through regressions) between individual metrics and environmental or geographical independent variables in the absence of anthropogenic impacts, i.e., from reference sites in other geographical regions. This method requires good quality ecological data and knowledge of the mechanisms that structure natural communities. Although being less direct than the spatial methods, under very specific conditions this process allows for the application of the reference data to an impervious area. If none of the existing sites in the watershed satisfies the criterion of "minimally impacted", the establishment of reference conditions by extrapolating measurements from other similar basins is still possible.

In spite of the variety of available methods for determining reference conditions, little knowledge and experience exists in most countries about the inherent positive and negative aspects, or about the potential problems associated to the use of each of them. In Table 1 Johnson (2001) summarizes the advantages and disadvantages of the different approaches. Where a single method does not produce a completely satisfactory vision of the undisturbed condition, we must compile all the available information into an integrated picture to obtain and calibrate reference conditions, just as is pointed out by Schmutz et al. (2000). 


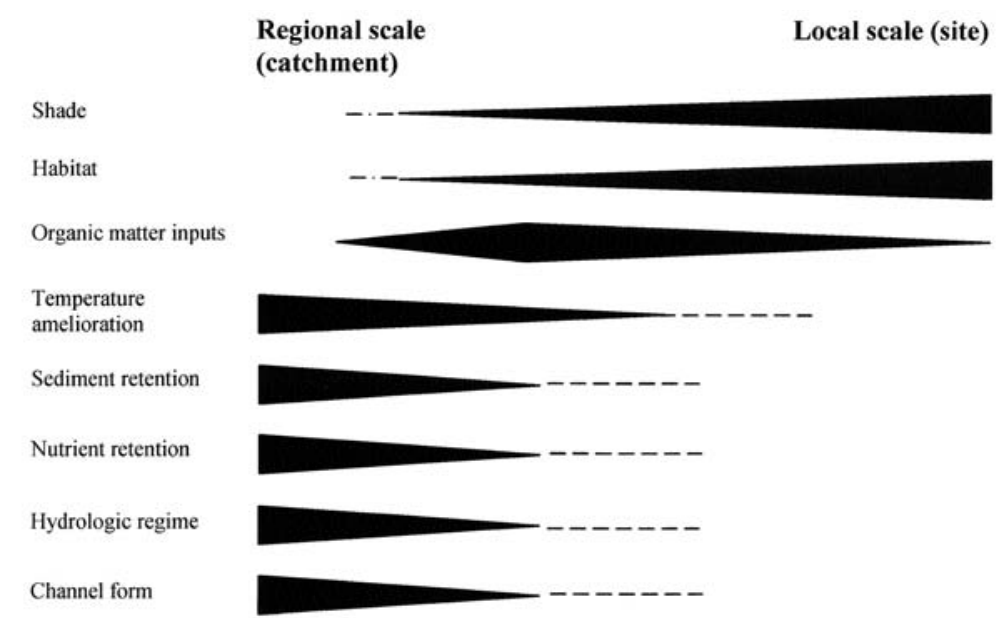

Figure 4. Theoretical influence exerted by the terrestrial vegetation, at the regional and local scale, on the structure and functioning of aquatic ecosystems (adapted from Allan et al., 1997). Influencia teórica ejercida por la vegetación terrestre, a la escala regional y local, en la estructura y funcionamiento de los ecosistemas acuáticos (adaptado de Allan et al., 1997).

\section{SPATIAL AND TEMPORAL SCALES OF ANALYSIS}

The study of stream ecology is based on patterns dependent on the interactions among multiple spatial and temporal scales, both involving rivers and the landscape through which they flow (Townsend, 1996). Authors like Maddock \& Bird (1996), Townsend \& Riley (1999), and Wiens (2002) point out that these links, important to the structure and functioning of rivers, operate in three spatial dimensions: (i) longitudinal links along the length of the river system (e.g. river continuum, nutrient spiraling, hyporheic corridor, and migration barriers along the river); (ii) lateral links with the adjacent terrestrial system (e.g. riparian influence); and (iii) vertical links with and through the river bed (e.g. organisms associated to the hyporheic zone, parafluvial processes). There is also a temporal dimension (e.g. daily, seasonal and annual variations, climatic cycles).

Rivers are hierarchically organized systems, whose higher scale characteristics influence the elements of smaller scales of the water courses, such as the habitat or microhabitat (Schumm 1977, Frissel et al., 1986; Sedell et al., 1990; Hildrew \& Giller, 1994). The works of Noss (1990) and Maddock (1999) emphasize the need to invest in a better understanding of the way the spatial and temporal dynamics of physical habi- tat determines river health. The landscape ecology that examines the interactions between spatial patterns and ecological processes in the context of spatial heterogeneity across a succession of scales may offer an interesting approach for linking the environmental descriptors along the riverine corridors (Ward et al., 2001). Indeed, there is a need of efficient tools that measure stream integrity at different scales, in other words, that are able to detect alterations, both at the watershed scale, which is used for management works (Walker \& Reuter, 1996), and at the segment scale and other lower spatial scales (Harris \& Silveira, 1999).

The relationships between environmental characteristics for multiple scales and the way they influence the aquatic organisms remain little tested and understood. Nevertheless, some skillful studies have provided evidence of the dependence of certain processes, such as organic matter inputs and channel structure, on very specific scales: the first processes seem to be controlled primarily by local factors, while the last ones are more influenced by superior scales (Allan et al., 1997) (Fig. 4). Also Osborne \& Wiley (1988) concluded that land use in the river's neighborhood was the main explanation for nutrient concentration in stream reaches. Roth et al. (1996) showed important links between landscape indicators in river integrity. 
Their works showed that riparian vegetation exercised a decisive role in the structuring of the habitats for fish with obvious consequences in these communities' composition. However, there are numerous other studies showing that variables that operate at larger spatial scales (e.g. geology, land use, and vegetation type) can be more important in influencing or controlling aquatic habitats and organisms than local ones (Parsons \& Norris, 1996; Richards et al., 1996; Marchant et al., 1997; Roth et al., 1996). Sutherland et al. (2002) consider that largescale patterns are usually better indicators (predictors) for monitoring ecosystem health since they exhibit lower temporal dynamism and resilience compared to habitat descriptors.

Ecological models that have been used for predicting macroinvertebrate species' responses to environmental stresses and habitat characteristics tend to neglect the temporal scales (most of the models are static) compared to their treatment of the spatial scales, because the underlying assumption is that the monitored communities present a high temporal persistence (Bunn \& Davies, 2000). However, when a time factor is present, it has been demonstrated that some communities show evidence of low persistence, which, in some cases (e.g. Faith et al., 1995), can be the result of inter-annual variation in environmental conditions. Low stability in the community structure has the potential of turning the construction of predictive models, like RIVPACS and AusRivAS, quite difficult, reducing its sensibility in terms of biomonitoring (Bunn \& Davies, 2000). More recent ecological integrity studies have, however, been greatly improved by the development of dynamic models that simultaneously capture the structure and the composition in systems affected by medium to long-term directional environmental disturbances (Cabral et al., 2001; Voinov et al., 2001). A rapid stochastic dynamic methodology (SDM) that links landscape patterns with the aquatic organisms has recently been developed and successfully applied in several types of basins in Portugal (Santos \& Cabral, 2003; Cabecinha et al., 2004).

The recognition of the importance of spatial scales for water resource management led us to develop a methodology for assessing the rivers in northern Portugal, relating the conditions that operate at the scale of drainage basin with the local conditions at the habitat level (physical and biological ) - (Oliveira \& Cortes, 2005). The integration of the temporal dynamics of invertebrate communities in the establishment of the reference conditions is present in the work of Oliveira \& Cortes (2006b). This, according to the same authors, avoids false interpretation resulting from peculiar environmental conditions, consequently turning the analysis more robust.

\section{THE CASE STUDIES}

A few case studies developed for North Portugal to demonstrate the use of innovative methodologies (through the conjugation of multimetric and multivariate statistical approaches, stochastic-dynamic models and/or making use of geographical information systems) in assessing the conservation status of water courses are summarized here. They represent an attempt to design integrated approaches to capture the aquatic ecosystems' complexity. Therefore, they incorporate several ecosystem components (e.g. physical, chemical, biological, and habitat) and several disturbance factors are assessed (e.g. clearance of riverine vegetation, sediment inputs in the river bed, destruction of habitat, diffuse and point-source pollution, etc.). Moreover, they incorporate different spatial and temporal scales of analysis and formulate procedures for establishing reference conditions.

These studies intend to provide methods that can be further refined for application in other regions and that provide the development of new assessment protocols contributing to an improvement of the management strategies of aquatic ecosystems. At a national scale, the methodologies proposed and the indexes produced aim to supply tools that can contribute to the implementation of the Water Framework Directive (WFD) in the next stage of the monitoring program definition. Figure 5 relates this research with the complexity of factors and techniques involved in biomonitoring that were previously described. 

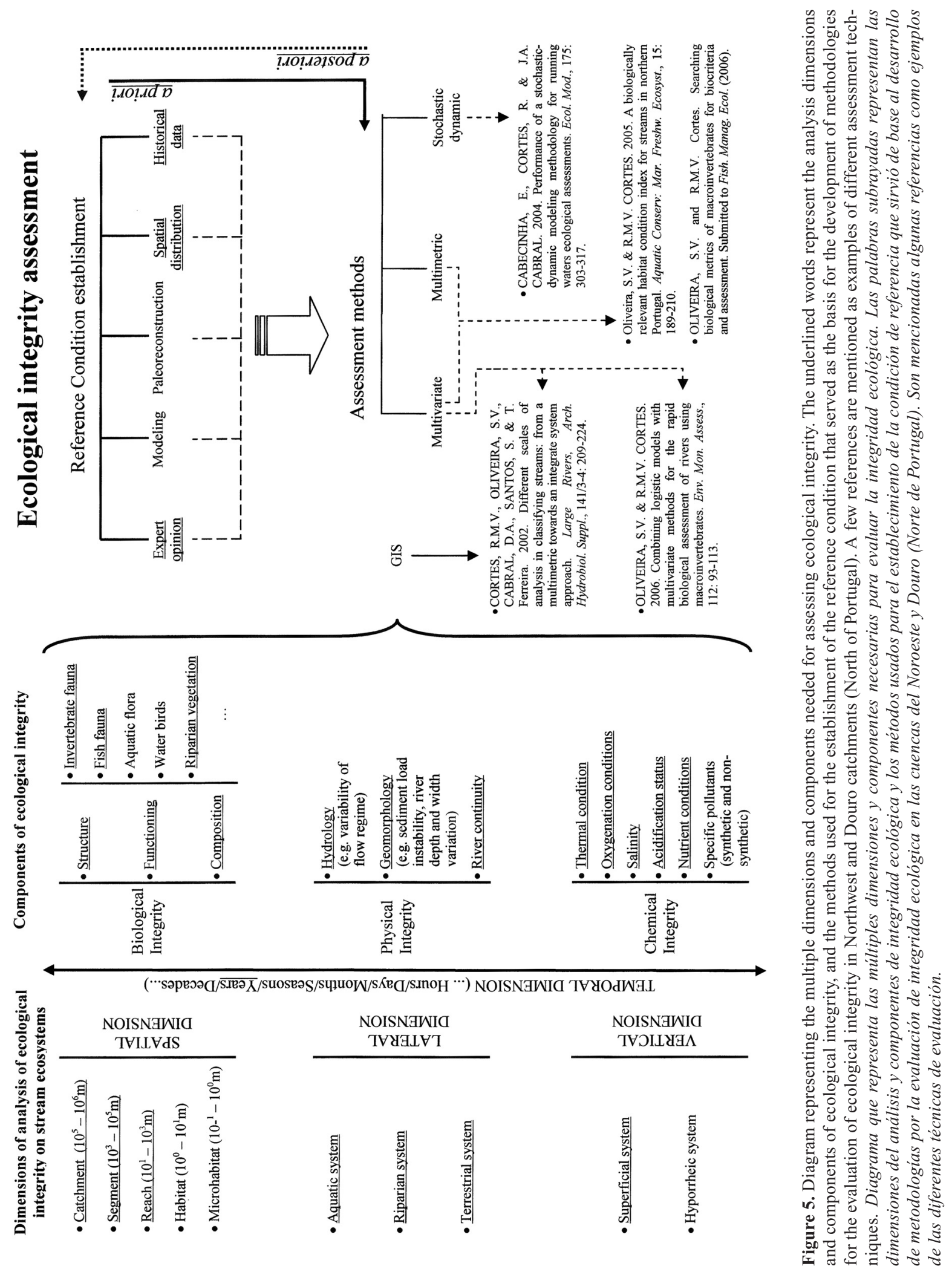


\section{Different scales of analysis in classifying streams: from a multimetric towards an integrate system approach (Cortes et al., 2002)}

Two different approaches to define the ecological status of several basins in NW, Portugal are compared. At the coarser scale, whole stream networks were classified using GIS according to variables related to: a) biotic indicators (native and exotic fish species, benthic biotic index, and characteristics of the riparian corridor); b) chemical indicators of contamination (industrial and urban organic loads, and water quality). This methodology was preceded by a typological classification, so that the ecological status could be determined separately for each of the physical units within a watercourse. At a finer scale, sites were categorized on the basis of the invertebrate fauna and the most relevant metrics were selected through multivariate procedures. These two methods can be seen as complementary and they produced similar indications of disturbance levels in spite of different assessment techniques and different space scales of analysis. By using the first method (assisted by GIS), we were able to identify the main typological gradients and the location of the most pristine segments. Relying on the classification displayed by this method at the basin scale, the second method enabled us to define with accuracy the sampling sites and the most convenient metrics for river health assessment.

\section{Performance of a stochastic-dynamic modeling methodology for ecological assessment of running waters (Cabecinha et al., 2004)}

A holistic stochastic-dynamic modeling methodology has been developed in order to predict the ecological status of lotic systems in Northeast Portugal. These procedures focus on the interactions between conceptually isolated key-components, such as some relevant benthic macroinvertebrate metrics and changes in local habitat conditions. The proposed model was preceded by a conventional multivariate statistical treatment performed to discriminate the significant relationships between prevailing biological and environmental variables. Since this statistical analysis is static, the dataset recorded from the field included true gradients of habitat changes. In this way, the time and space factors are implicit in the respective treatment. Such a procedure gives credibility to the parameters included in the construction of the dynamic model. In order to enhance the importance of monitoring in aquatic systems based on ecological integrity indicators, different biotic metrics were selected from the studied benthic macroinvertebrate communities. The model validation was based on independent data from another watershed not included in the construction of the model. Thereafter, the model behaviour was tested facing a "new" scenario, namely ongoing organic pollution disturbances in the region. The results are encouraging since, after validation, the reliability of the model was demonstrated: (1) to assess the ecological status of running waters from the studied watersheds, and (2) to predict the behaviour of key macroinvertebrate metrics, along disturbance gradients described by physical and chemical parameters.

\section{A biologically relevant habitat condition index for streams in northern Portugal (Oliveira \& Cortes, 2005)}

This work describes the development of an index for assessing stream habitats at a variety of spatial scales and levels of perturbation. A large set of environmental variables (86) was used, including regional and local ones, reflecting the geo-morphological characteristics and human activities occurring in each basin as well as variables describing the riverine habitat.

Collections of benthic invertebrates were made at each sample site. To reflect the observed variation in assemblages the streams were separated into basin groups.

Multivariate analysis techniques applied to the physical and biological data sets allowed the determination of the relative importance of local and regional environmental descriptors responsible for the discrimination of the invertebrate assemblages. 
Successive statistical refinement procedures yielded ten variables as a final selection of all of them representing local scale factors. The analysis of their variation along disturbance gradients allowed the development of the habitat index through scoring criteria that separated reference from stressed sites.

The results indicate the reduced contribution of basin factors due to a buffering influence probably resulting from a riparian corridor, which made the index developed to be related to in-stream and surrounding habitat descriptors.

\section{Combining logistic models with multivariate methods for the rapid biological assessment of rivers using macroinvertebrates (Oliveira \& Cortes, 2006a)}

The technique developed in this study is based on a predictive model that allows the classification of the relative degree of disturbance of test sites in lotic systems, on the basis of a comparison of their faunistic composition with reference sites. Two ecotypes were selected where benthic invertebrates were sampled in reaches with different levels of contamination.

As a first stage, previous GIS information was used to define the reference sites in each ecotype. Afterwards, multivariate techniques and nonlinear estimation models were combined to assess biological quality. This method allowed us to classify sites according to increasing levels of contamination, after the probabilities of occurrence of taxa along a gradient of contamination taking into account the reference condition.

The results suggest that this method is sensitive to organic pollution, easy to interpret by ranking species according to their tolerance, and could be a good framework for monitoring in areas where there is a lack of relevant ecological information.

\section{Searching biological metrics of macroinvertebrates for biocriteria and assessment (Oliveira \& Cortes, 2006b)}

From a large set of 184 metrics describing the benthic community, grouped into 16 biological categories selected from literature, a procedure
Table 2. Major features of biomarkers and bioindicators for use in bio-assessment studies (from Adams, 2002). Principales caracteristicas de los biomarcadores y bioindicadores para el uso en estudios de evaluación biológica (de Adams, 2002).

\begin{tabular}{lll}
\hline \multicolumn{1}{c}{ Major features } & \multicolumn{1}{c}{ Biomarkers } & \multicolumn{1}{c}{ Bioindicators } \\
\hline Types of response & Subcellular, cellular & $\begin{array}{l}\text { Individual trough } \\
\text { community }\end{array}$ \\
Primary indicators of & Exposure & Effects \\
Sensitivity to stressors & High & Low \\
Relationship to cause & High & Low \\
Response variability & High & Low-moderate \\
Specificity to stressors & Moderate-high & Low \\
Time scale of response & Short & Long \\
Ecological relevance & Low & High \\
\hline
\end{tabular}

was defined to select the most relevant ones in assessing the ecological condition.

The data consisted of 54 sites from 31 rivers of the Douro Basin, covering the whole range of environmental conditions and collected in two different years (1997 and 2000) during the summer period.

Multivariate analyses (n-MDS with SIMPER test and CCA) were carried out to identify the main patterns of macroinvertebrate data, to select reference versus impaired sites, to avoid multico-linearity between metrics, and to achieve independence from the natural stream typology. The chosen metrics proved to be the most effective, that is, they exhibited a response across a range of human influence. We believe that these attributes are ecologically sound and therefore, in the future, can be used in the assessment and monitoring of aquatic ecosystems in Portugal and may also provide information relevant to the Water Framework Directive (WFD).

\section{FURTHER DEVELOPMENTS IN BIOMONITORING: INTEGRATING DIFFERENT LEVELS OF BIOLOGICAL ORGANIZATION}

Complete bio-monitoring must be achieved along different levels of biological organization, from the sub-cellular and cellular observation, following increasing scales like tissue and organ analysis to the population and community level. The organism-level response provides an inter- 
mediate and pivotal point that links the mechanistic basis (related to lower levels) with the ecological significance (specific to higher levels, like community structure and composition).

Bio-criteria includes biomarkers and bioindicators. The first ones are used at the lowest levels of biological organization and are considered to be functional measures of exposure to environmental stress. Biomarkers such as molecular, biochemical, or physiological endpoints are applied primarily to indicate that an organism was exposed to a stressor, such as a xenobiotic chemical. For instance, molecular biomarkers are based on the alteration of macromolecules (nucleic proteins, lipids, or carbohydrates). Their structural and functional alteration can be used as an indication of xenobiotic exposure, effect and susceptibility to toxicant-induced diseases (Wirgin \& Theodorakis, 2002). Physiological responses to stressors include primary effects, such as neuroendocrine response like the release of cathecolamines, or secondary ones, measured by changes in plasma and tissue ions, metabolite levels, and haematological features (Mommsen et al., 1999).

Biomarkers and bioindicators have advantages and limitations (Table 2). In general biomarkers are stressor sensitive and of rapid response, helping to establish the cause-effect link; bioindicators, on the contrary, do not allow for the understanding of the underlying causal mechanisms, but rather integrate the effects of multiple stressors over large spatial and temporal scales (Adams, 2002).

However, biomonitoring is divided in different compartments and there is no integration of the different levels of analysis. For instance, biomarkers that that have been calibrated and correlated with higher-level effects, such as population or community attributes, can indeed serve as valid bioindicators (Adams, 2000). The main challenge for the future must be to group information from the different scales of biological organization, for instance by including metrics at the different levels and trying their integration into several types of indices for practical use. We must recognize that nowadays, in the assessment of river health, there are already a few attempts (but still very scarce) to incorporate various levels of analysis in the biota. For instance, some metrics include histopathological observations: the detection of lesions represents an integration of cumulative effects of biochemical and physiological changes in specific cells and organs (Myers \& Fournie, 2002), which may be combined with metrics at higher levels like species richness or characteristics of food chain.

\section{REFERENCES}

ADAMS, S. M. 2002. Biological indicators of aquatic ecosystem stress: introduction and overview. In: Biological Indicators of Aquatic Ecosystem Stress. S.M. Adams (ed.): 1-11. American Fisheries Society, Maryland, USA.

ALLAN, J. D., D. L. ERICKSON \& J. FAY. 1997. The influence of catchment land use on stream integrity across multiple spatial scales. Freshwat. Biol., 37: 149-161.

ANGERMEIER, P. L. \& J. R. KARR. 1994. Biological integrity versus biological diversity as policy directives. BioScience, 44: 690-697.

BARBOUR, M. T., J. GERRITSEN, G. E. GRIFFITH, R. FRYDENBORG, E. McCARRON, J. S. WHITE \& M. L. BASTIAN. 1996. A framework for biological criteria for Florida streams using benthic macroinvertebrates. J. North Am. Benthol. Soc., 15: 185-211.

BARBOUR, M. T., J. GERRITSEN, B. D. SNYDER \& J. B. STRIBLING. 1999. Rapid Bioassessment Protocols for use in Streams and Wadeable Rivers: periphyton, benthic macroinvertebrates and fish, Second Edition. EPA 841-B-99-002 U.S. Environmental Protection Agency, Office of Water, Washington, D.C. (http:www.epa.gov/OWOW/monitoring/ techmon.html).

BARBOUR, M. T., W. F. SWIETLIK, S. K. JACKSON, D. L. COURTEMANCH, S. P. DAVIES \& C. O. YODER. 2000. Measuring the attainment of biological integrity in the USA: a critical element of ecological integrity. Hydrobiologia, 422/423: 453-464.

BRADFORD, D. F., S. E. FRANSON, A. C. NEALE, D. T. HEGGEM, G. R. MILLER \& G. E. CANTERBURY. 1998. Bird species assemblages as indicators of biological integrity in Great Basin rangeland, Environmental Monitoring and Assessment, 49: 1-22. 
BUNN, S. E. \& P. M. DAVIES. 2000. Biological processes in running waters and their implications for the assessment of ecological integrity. Hydrobiologia, 422/423: 61-70.

CABECINHA, E., R. CORTES \& J. A. CABRAL. 2004. Performance of a stochastic-dynamic modelling methodology for running water ecological assessments. Ecological Modelling, 175: 303-317.

CABRAL, J. A., J. C. MARQUES \& S. N. NIELSEN. 2001. Modeling mosquitofish (Gambusia holbrooki) responses to Genapol OXD-080, a nonionic surfactant, in rice fields. Ecological Engineering, 16, 537-544.

CAMPBELL, D. E. 2000. Using energy systems theory to define, measure, and interpret ecological integrity and ecological health. Ecosystem Health, 6: 181-204.

CORTES, R. M. V., S. V. OLIVEIRA, D. A. CABRAL, S. SANTOS \& T. FERREIRA. 2002. Different scales of analysis in classifying streams: from a multimetric towards an integrate system approach. Large Rivers, Arch. Hydrobiol. Suppl., 141/3-4: 209-224.

DAVIES, P. E. 2000. Development of a national river bioassessment system (AUSRIVAS) in Australia. In: Assessing the biological quality of fresh waters: RIVPACS and other techniques. J. F. Wright, D. W. Sutcliffe \& M. T. Furse (eds.): 113124. Freshwater Biological Association, Ambleside, Cumbria, UK.

DAVIES, W. S. \& T. P. SIMON. 1995. Biological assessment and criteria. Tools for water resource planning and decision making. Lewis Publishers, Boca Raton, Florida. 415 pp.

De PAUW, N. 2000. Using RIVPACS as a modelling tool to predict the impacts of environmental changes. In: Assessing the biological quality of fresh waters: RIVPACS and other techniques. J. F. Wright, D. W Sutcliffe \& M. T. Furse (eds.): 311314. Freshwater Biological Association, Ambleside, Cumbria, U.K.

De PAUW, N. \& G. VANHOREN. 1983. Method for biological quality assessment of water courses in Belgium. Hydrobiologia, 100: 153-168.

ECONOMOU, A. N., S. SCHMUTZ, A. MELCHER, G. HAIDVOGL, J. BREINE, I. SIMOENS, P. KESTEMONT, D. GOFFAUX, D. PONT, J. BÖHMER, V. KESMINAS, T. VIRBICKAS, M. ZALEWSKI, M. LAPINSKA, J. BACKX, J. J. De LEEUW, T. FERREIRA, U. BEIER, E. DEGERMAN, I. G. COWX, R. A. A. NOBLE, \& A. STARKIE. 2002. Development, evaluation \& implementation of a standardized fish-based assessment method for the ecological status of European Rivers - a contribution to the Water Framework Directive (FAME). Defining Reference Condition (D3). Final Report. 57 pp.

EDWARDS, C. J. \& R. A. RYDER. 1990. Biological Surrogates of mesotrophic ecosystem health in the Laurentian Great Lakes, 69 pp.

EPA - Environmental Protection Agency. 1998. 40 CFR Part 131. Water Qaulity Standards Regulation. Federal Register/ Vol. 63, No. 129/Tuesday, July 7/ Proposed Rules.

FAIRWEATHER, P. G. 1999. State of environment indicators of "river health": exploring the metaphor. Freshwat. Biol., 41: 211-220.

FAITH, D. P., P. L. DOSTINE \& C. L. HUMPHREY. 1995. Detection of mining impacts on aquatic macroinvertebrate communities: results of a disturbance experiment and the design of a multivariate BACIP monitoring program at Coronation Hill, Northern Territory. Australian Journal of Ecology, 20: 167-180.

FORE, L. S. \& J. R. KARR. 1996. Assessing invertebrate responses to human activities: evaluating alternative approaches. J. North Am. Benthol. Soc., 15: 212-231.

FRISSEL, C. A., W. J. LISS, C. E. WARREN \& M.D. HURLEY. 1986. A hierarchical framework for stream habitat classification. Environmental Management, 10: 199-214.

HARRIS, J. H. \& R. SILVEIRA. 1999. Large-scale assessments of river health using an Index of Biotic Integrity with low-diversity fish communities. Freshwat. Biol., 41: 235-252.

HILDREW, A. G. \& P. S. GILLER. 1994. Patchiness, species interactions and disturbance in the stream benthos. In: Aquatic Ecology: scale, patterns and process. P.S. Giller, A.G. Hildrew \& D.G. Raffaelli (eds.): 21-61. Blackwell Scientific Publications, Cambridge MA.

HUGHES, R. M. 1995. Defining acceptable biological status by comparing with reference conditions. In: Biological Assessment and Criteria. Tools for Water Resource Planning and Decision Making. W.S. Davis \& T.P. Simon (eds.): 31-47. Lewis Publishers, Boca Raton, Florida.

HUGHES, R. M. \& D. P. LARSEN.1987. Ecoregions: an approach to surface water protection. Journal of the Water Pollution Control Federation, 60: 486-493.

HUGHES, R. M., D. P. LARSEN \& J. M. OMERNIK. 1986. Regional reference sites: a method for 
assessing stream potentials. Environmental management, 10: 629-635.

HYLAND, J. L., T. R. SNOOTS \& W. L. BALTHIS. 1998. Sediment quality of estuaries in the southeastern U.S. Environmental Monitoring and Assessment, 51: 331-343.

JACKSON, L. E., J. C. KURTZ \& W. S. FISHER. 2000. Evaluation guidelines for ecological indicators. EPA/620/R-99/005. U.S. Environmental Protection Agency, Office of Research and Development, Research Triangle Park, NC. 107 pp.

JOHNSON, R. K. 2000. RIVPACS and alternative statistical modeling techniques: accuracy and soundness of principles. In: Assessing the biological quality of fresh waters: RIVPACS and other techniques. J. F Wright, D. W. Sutcliffe \& M. T. Furse (ed.): 323-332. Freshwater Biological Association, Ambleside, Cumbria, U.K.

JOHNSON, R. K. 2001. Defining reference conditions and setting class boundaries in ecological monitoring and assessment. Background Document, REFCOND project, $13 \mathrm{pp}$.

KARR, J. R. 1981. Assessment of biotic integrity using fish communities. Fisheries, 6: 21-27.

KARR, J. R. 1991. Biological integrity: a long neglected aspect of water resource management. Ecological Applications, 1: 66-84.

KARR, J. R. 1992. Ecological integrity. Protecting earth's life support systems. In: Ecosystem Health. R. Constanza, B.G. Norton \& B.D. Haskell (eds.): 223-238. Island Press, Washington, D.C.

KARR, J. R. 1999. Defining and measuring river health. Freshwat. Biol., 41: 221-234.

KARR, J. R \& E. W. CHU. 1999. Restoring life in running waters. Island Press, Washington, D.C., $206 \mathrm{pp}$.

KARR, J. R. \& E. W. CHU. 2000. Sustaining living rivers. Hydrobiologia, 422/423: 1-14.

KARR, J. R. \& D. R. DUDLEY. 1981. Ecological perspective on water quality goals. Environmental Management, 5: 55-68.

KARR, J. R., K. D. FAUSCH, P. L. ANGERMEIER, P. R. YANT \& I. J. SCHLOSSER. 1986. Assessing biological integrity in running waters: a method and its rationale. Illinois Natural History Survey, Urbana, Illinois. Special Publication no. 5. 28 pp.

KLEMM, D. J., K. A. BLOCKSOM, F. A. FULK, A. T. HERLIHY, R. M. HUGHES, P. R. KAUFMANN, D. V. PECK, J. L. STODDARD, W. T. THOENY \& M. B. GRIFFITH. 2003. Development and evaluation of a macroinvertebrate biotic integrity index (MBII) for regionally asses- sing Mid-Atlantic Highlands streams. Environmental Management, 31: 656-669.

MADDOCK, I. 1999. The importance of physical habitat assessments for evaluating river health. Freshwat. Biol., 41: 373-391.

MADDOCK, I. P. \& D. BIRD. 1996. The application of habitat mapping to identify representative PHABSIM sites on the River Tavy, Devon, UK. Proceedings of the $2^{\text {nd }}$ International Symposium on Habitats and Hydraulics, Vol. B, M. Leclerc, H. Capra, S. Valentin, A. Boudreault \& I. Cote (eds.): 203-214. Quebec, Canada.

MARCHANT, R., HIRST, A., NORRIS, R. H., BUTCHER, R., METZELING, L. \& D. TILLER. 1997. Classification and prediction of macroinvertebrates assemblages from running waters in Victoria, Australia. J. North Am. Benthol. Soc., 16: 664-681.

MINSHALL, G. W. 1988. Stream ecosystem theory: a global perspective. J. North Am. Benthol. Soc., 7: 263-288.

MOMMSEN, T. P., M. M. VIJAYAN \& T. W. MOON. 1999. Cortisol in teleosts: dynamics, mechanisms of action, and metabolic regulation. Reviews in Fish Biology and Fisheries, 9: 211-268.

MYERS, M. S. \& J. W. FOURNIE. 2002. Histopathological biomarkers as integrators of anthropogenic stressors. In: Biological Indicators of Aquatic Ecosystem Stress. S. M. Adams (ed.): 221-287. American Fisheries Society, Maryland, USA.

NORRIS, R. H. \& M. C. THOMS. 1999. What is river health? Freshwat. Biol., 41: 197-209.

NOSS, R. F. 1990. Indicators for monitoring biodiversity: a hierarchical approach. Conservation Biology, 4: 31-48.

NRA. 1996. River habitats in England and Wales: a national overview. River Habitat Survey Report no. 1. National Rivers Authority, Bristol. 53 pp.

OEPA. 1987. Biological criteria for the protection of aquatic life, Volume II: Users Manual for biological field assessment of Ohio surface waters. Ohio Environmental Protection Agency (Ohio EPA), Ecological Assessment Section, Division of Water Quality, Columbus, Ohio. 251 pp.

OEPA. 1989. Biological criteria for the protection of aquatic life, Volume III. Standardized biological field sampling and laboratory methods for assessing fish and macroinvertebrate communities. Ohio Environmental Protection Agency (Ohio EPA), Columbus, Ohio. 57 pp.

OEPA. 1990. Water quality program highlights. United States Environmental Protection Agency, 
Assessment and Watershed Protection Division, Office of Water, Washington, DC 20460. 4 pp.

OLIVEIRA, S. V. \& R. M. V. CORTES. 2005. A biologically relevant habitat condition índex for streams in northern Portugal. Aquatic Conservation: Marine and Freshwater Ecosystems, 15: 189-210.

OLIVEIRA, S. V. \& R. M. V. CORTES. 2006a. Combining logistic models with multivariate methods for the rapid biological assessment of rivers using macroinvertebrates. Environmental Monitoring and Assessment, 112: 93-113.

OLIVEIRA, S. V. \& R. M. V. CORTES. 2006 b. Searching biological metrics of macroinvertebrates for biocriteria and assessment. Submitted to Fisheries Management and Ecology.

OMERNIK, J. M. 1987. Ecoregions of the conterminous United States. Annals of the Association of American Geography, 77: 118-125.

OMERNIK, J. M. 1995. Ecoregions: a spatial framework for environmental management. In: Biological Assessment Criteria: Tools for Water Resource Planning and Decision-Making. W. S. Davis \& T. Simon (eds.): 49-62. Lewis Publishers, Boca Raton, FL.

OSBORNE, L. L \& M. J. WILEY. 1988. Empirical relationships between land use/cover and stream water quality in an agricultural watershed. Journal of Environmental Management, 26: 9-27.

PARSONS, M. \& R. H. NORRIS. 1996. The effect of habitat-specific sampling on biological assessment of water quality using a predictive model. Freshwat. Biol., 36: 419-434.

PETTS, G. E. 1989. Historical analysis of fluvial hydro-systems. In: Historical Change of Large Alluvial Rivers: Western Europe. G. E. Petts, H. Moller \& A. L. Roux (eds.): 1-18. Wiley, Chichester.

PLAFKIN, J. L, M. T. BARBOUR, K. D. PORTER, S. K. GROSS \& R. M. HUGHES. 1989. Rapid bioassessment protocols for use in streams and rivers: Benthic macroinvertebrates and fish. EPA/444/4-89-001 U.S. Environmental Protection Agency. Washington, D.C. 196 pp.

POFF, N. L. \& J. V. WARD. 1989. Implications of streamflow variability and predictability for lotic community structure: a regional analysis of streamflow patterns. Can. J. Fish. Aquat. Sci., 46: 1805-1818.

RAKOCINSKI, C. F., S. S. BROWN, G. R. GASTON, R. W. HEARD, W. W. WALKER \& J. K. SUMMERS. 1997. Macrobenthic responses to natural a contaminant-related gradients in northern Gulph of Mexico estuaries. Ecological Applications, 7: 1278-1298.
RAPPORT, D. J., R. CONSTANZA \& A. J. McMICHAEL. 1998. Assessing ecosystem health. Trends in Ecology and Evolution, 13: 397-402.

REFCOND GUIDANCE. 2003. Guidance on establishing reference conditions and ecological status class boundaries for inland surface waters. Produced by Working Group 2.3 - Reference conditions for inland surface waters. $86 \mathrm{pp}$.

REYNOLDSON, T. B., R. C. BAILEY, K. E. DAY \& R. H. NORRIS. 1995. Biological guidelines for freshwater sediment based on Benthic Assesssment of SedimenT (the BEAST) using a multivariate approach for predicting biological state. Australian Journal of Ecology, 20: 198-219.

REYNOLDSON, T. B., R. H. NORRIS, V. H. RESH, K. E. DAY \& D. M. ROSENBERG. 1997. The reference condition: a comparison of multimetric and multivariate approaches to assess water-quality impairment using benthic macroinvertebrates. J. North Am. Benthol. Soc., 16: 833-852.

RICHARDS, C., JOHNSON, L. B. \& G. E. HOST. 1996. Land-scape-scale influences on stream habitats and biota. Can. J. Fish. Aquat. Sci., 53(Suppl. 1): 295-311.

ROSENBERG, D. M. \& V. H. RESH. 1993. Freshwater biomonitoring and benthic macroinvertebrates. Chapman and Hall, New York. 488 pp.

ROSENBERG, D. M., T. B. REYNOLDSON \& V. H. RESH. 2000. Establishing reference conditions in the Fraser River catchment, British Columbia, Canada, using the BEAST (Benthic Assessment of Sediment) predictive model. In: Assessing the biological quality of fresh waters: RIVPACS and other techniques. J. F. Wright, D. W. Sutcliffe \& M. T. Furse (eds.): 181-194. Freshwater Biological Association, Ambleside, Cumbria, U.K.

ROSGEN, D. L. 1994. A classification of natural rivers. Catena, 22: 169-199.

ROSGEN, D. L. 1996. Applied River Morphology. Wildland Hydrology, Pagosa Springs, CO. 390 pp.

ROTH, N. E., J. D. ALLAN \& D. L. ERICKSON. 1996. Landscape influences on stream biotic integrity assessed at multiple spatial scales. Landscape Ecology, 11(3): 141-156.

SANTOS, M. \& J. A. CABRAL. 2003. Development of a stochastic dynamic model for ecological indicators prediction in changed Mediterranean agroecosystems of north-eastern Portugal. Ecological Indicators, 3: 285-303.

SEDELL, J. R., G. H. REEVES, F. R. HAUER, J. A. STANFORD \& C. P. HAWKINS. 1990. Role of refugia in recovery from disturbances: modern 
fragmented and disconnected river systems. Environmental Management, 14: 711-724.

SCHMUTZ, S., M. KAUFMAN, B. VOGEL, M. JUNGWIRTH \& S. MUHAR. 2000. A multi-level concept for fish-based, river-type-specific assessment of ecological integrity. Hydrobiologia, 422/423: 279-289.

SCHUMM, S. A. 1977. The fluvial system. WileyInter-science Publication, Sydney. 338 pp.

SCHOFIELD, N. J. \& P. E. DAVIES. 1996. Measuring the health of our rivers. Water (Australia), 23: 39-43.

SIMPSON, J. C. \& R. H. NORRIS. 2000. Biological assessment of river quality: development of AUSRIVAS models and outputs. In: Assessing the biological quality of fresh waters: RIVPACS and other techniques. J. F. Wright, D. W. Sutcliffe \& M. T. Furse (eds.): 125-142. Freshwater Biological Association, Ambleside, Cumbria, U.K.

SMITH, J. A. 1994. Sediment toxicity testing: battery test evaluation of shallow urban streams and the effect of sampling method on toxicity. MASc. Dept. of Civil Engr., The University of British Columbia, Vancouver, B.C. 121 pp.

SUTER, I. G. W. 1993. A critique of ecosystem health concepts and indexes. Journal of the Society of Environmental Toxicology and Chemistry, 12: 1533-1539.

SUTHERLAND, T. F., C. D. LEVINGS, J. M. HELFIELD, B. T. HARGRAVE, W. KNAPP \& D. STUCCHI. 2002. Research tools in support of habitat management priorities. In: Environmental Studies for Sustainable Aquaculture (ESSA). B. T. Hargrave (ed.): 5-8. Workshop report. Can. Tech. Rep. Fish. Aquat. Sci. 2411: v 117 p.

THOMS, M. C., R. W. OGDEN \& M. A. REID. 1999. Establishing the condition of lowland floodplain rivers: a palaeo-ecological approach. Freshwat. Biol., 41: 407-423.

TOWNSEND, C. R. 1996. Concepts in river ecology: pattern and process in the catchment hierarchy. Archiv fur Hydrobiologie (Suppl. 113), Large Rivers, 10: 3-21.

TOWNSEND, C. R. \& A. G. HILDREW. 1994. Species traits in relation to a habitat templet for river systems. Freshwat. Biol., 31: 265-276.

TOWNSEND, C. R. \& R. H. RILEY. 1999. Assessment of river health: accounting for perturbation pathways in physical and ecological space. Freshwat. Biol., 41: 393-405.

VOINOV, A., R. CONSTANZA, L. A. WAINGER, R. BAUMANS, F. VILLA, T. MAXWELL \& H.
VOINOV. 2001. Patuxent landscape model: integrated ecological economic modeling of a watershed. Environmental Modelling \& Software, 14: 473-491.

WALKER, J. \& D. J. REUTER. (eds.). Indicators of catchment health. A technical perspective. CSIRO, Australia. $174 \mathrm{pp}$.

WARD, J. V., K. TOCKNER, U. UEHLINGER \& F. MALARD. 2001. Understanding natural patterns and processes in river corridors as the basis for effective river restoration. Regulated Rivers: Research \& Management, 17: 311-323.

WIENS, J. A. 2002. Riverine landscapes: taking landscape ecology into the water. Freshwater Biology, 47: 501-515.

WIRGIN, I. I. \& C. W. THEODORAKIS. 2002. Molecular biomarkers in aquatic organisms: DNA damage and RNA expression. In: Biological Indicators of Aquatic Ecosystem Stress. Ed: S.M. Adams (ed.): 43-110. American Fisheries Society, Maryland, USA.

WRIGHT, J. F. 1995. Development and use of a system for predicting the macroinvertebrate fauna in flowing waters. Australian Journal of Ecology, 20, 181-197.

WRIGHT, J. F. 2000. An introduction to RIVPACS. In: Assessing the biological quality of fresh waters: RIVPACS and other techniques. J. F. Wright, D. W. Sutcliffe \& M. T. Furse (eds.): 1-23. Freshwater Biological Association, Ambleside, Cumbria, U.K.

WRIGHT, J. F., FURSE, M. T. \& P. D. ARMITAGE. 1994. Use of macroinvertebrate communities to detect environmental stress in running waters. In: Water quality and stress indicators in marine and freshwater systems: linking levels of organization. D. W. Sutcliffe (ed.): 15-34. The Freshwater Biological Association, Ambleside.

WRIGHT, J. F., B. MOSS, P. D. ARMITAGE \& M. T. FURSE. 1984. A preliminary classification of running-water sites in Great Britain based on macroinvertebrate species and the prediction of community type using environmental data. Freshwat. Biol., 14: 221-256.

YODER, C. O. 1995. Policy issues and management applications for biological criteria. In: Biological assessment and criteria: tools for water resource planning and decision making. W.S. Davis \& T.P. Simon (eds.): 327-343. Lewis Publishers, Boca Raton.

YODER, C. O. \& E. T. RAKIN. 1998. The role of biological indicators in a state water quality management process. Environmental Monitoring and Assessment, 51: 61-88. 